\title{
Prevalence and risk factors associated with traumatic dental injury among 12-year-old schoolchildren in Montes Claros, MG, Brazil
}

\author{
Prevalência e fatores de risco associados ao traumatismo dentário \\ em escolares de 12 anos de idade em Montes Claros, Minas Gerais, \\ Brazil
}

\author{
Paula Cristina Pelli Paiva ${ }^{1}$ \\ Haroldo Neves de Paiva ${ }^{2}$ \\ Paulo Messias de Oliveira Filho ${ }^{3}$ \\ Maria Ilma de Souza Côrtes ${ }^{4}$
}

${ }^{1}$ Programa de Pós-

Graduação em Ciências

da Saúde, Faculdade de

Medicina, Universidade

Federal de Minas Gerais. Av.

Professor Alfredo Balena

190, Santa Efigênia. 30130-

100 Belo Horizonte MG

Brasil. paulacpp@ig.com.br

${ }^{2}$ Departamento de

Odontologia, Universidade

Federal dos Vales do

Jequitinhonha e Mucuri.

${ }^{3}$ Departamento de Ciências

Básicas, Universidade

Federal dos Vales do

Jequitinhonha e Mucuri.

${ }^{4}$ Faculdade de Odontologia,

Pontifícia Universidade

Católica de Minas Gerais.

\begin{abstract}
The scope of this study was to determine the prevalence of trauma in the permanent dentition of 12-year-old schoolchildren and assess associations with demographic factors such as gender and socioeconomic status and overjet and lip coverage clinical factors. A cross-sectional analysis was conducted using a representative sample of 638 students. Data were gathered by means of clinical examinations and self-administered questionnaires. Descriptive analysis was performed, followed by the use of the chi-square test and Poisson logistic regression model for the determination of significant associations. The prevalence of traumatic dental injury was $34.9 \%$. Falls constituted the main etiological factor (49.7\%), and occurred in the home (48.2\%). The results of the Poisson regression analysis revealed that accentuated overjet $(>5 \mathrm{~mm})$ remained associated with traumatic dental injury irrespective of the other variables $[P R=1.50$ (95\% CI: 1.41 to $1.61) ; p=0.003]$. Moreover, a statistically significant association was found between accentuated overjet and dental trauma. No significant associations were found between TDI and socioeconomic status. These findings highlight the need for prevention strategies and orthodontic correction at the onset of the permanent dentition.
\end{abstract}

Key words Dental trauma, Schoolchildren, Adolescents, Fractures, Oral health
Resumo Introdução: O objetivo do presente estudo foi determinar a prevalência de traumatismo dentário na dentição permanente em escolares de 12 anos de idade e sua associação com fatores demográficos (gênero e condição socioeconômica) e clínicos (sobressaliência acentuada e proteção labial). Metodologia: Um estudo transversal foi realizado em uma amostra representativa de 638 escolares. Dados foram coletados por exame clínico e questionário autoaplicável. Foram realizadas análises descritivas, seguidas do teste quiquadrado e modelo de regressão de Poisson para determinar associações. Resultados: A prevalência de traumatismo dentário foi de 34,9\%. Queda foi o principal fator etiológico (49,7\%). Os resultados da regressão logística de Poisson revelaram que o aumento do overjet ( $>5 \mathrm{~mm}$ ) se manteve associado aos traumatismos dentários de forma independente das demais variáveis $[P R=1.50$ (95\% CI: 1.41 to 1.61); $p=0.003]$. Conclusão: Associação estatisticamente significativa foi observada entre aumento do overjet e presença de traumatismo dentário. Não foi observada associação estatística entre os traumatismos dentários e a condição socioeconômica. Os resultados encontrados sugerem a necessidade de estratégias de prevenção e correção ortodôntica na dentição permanente.

Palavras-chave Traumatismos dentários, Estudantes, Adolescentes, Fraturas, Saúde Bucal 


\section{Introduction}

Traumatic dental injuries (TDIs) are considered a public health problem due to their high prevalence rate ${ }^{1-27}$, extensive knowledge of their etiology, which allows the establishment of prevention strategies ${ }^{1,5,9-10,28}$, and the high costs of such injuries, such as the direct cost of treatment ${ }^{29}$, indirect costs linked to missing days of work and school $^{30}$ and the impact of dental trauma on quality of life $\mathrm{f}^{31-33}$.

The prevalence of TDI reported in population-based studies ranges from $6 \% 13$ to $17.7 \%{ }^{21}$ in international studies, but is higher in national studies, such as the $10.5 \%$ rate reported by Soriano et al. ${ }^{19}$ and the $58.6 \%$ rate reported by Marcenes et al. ${ }^{6}$. In the past 20 years, the number of articles on TDI has increased in Brazil, which is currently one of the leading countries in dental trauma research. However, a small number of studies have addressed children aged 12 years, which coincides with the end of the mixed dentition phase and is a time in life when children participate more in sports and games involving bodily contact ${ }^{16,34}$.

Predisposing factors, such as inadequate lip coverage and increased overjet, have been widely investigated in studies on traumatic dental injuries. However, the health of a population is also influenced by demographic, socioeconomic and behavioral factors ${ }^{35}$. A small number of studies have correlated the prevalence of permanent tooth injury and socioeconomic indicators. Moreover, the divergent findings demonstrate that the association between these variables remains unclear. This discrepancy is likely due to methodological differences among studies and the few papers published on this issue, which underlines the need for further investigation into the association between socioeconomic status and $\mathrm{TDI}^{16,17}$.

The aims of the present study were to determine the prevalence of trauma in the permanent dentition of 12-year-old schoolchildren and assess associations with socioeconomic indicators (social class, mother schooling and marital status of the legal guardian). Clinical factors, the type of injury, etiology, place of trauma and age at the time of occurrence were also evaluated.

\section{Methods}

The study was conducted in Montes Claros, a medium-sized town located in the north region of the state of Minas Gerais in the south east of Brazil with 361,914 inhabitants. Montes Claros has 174 elementary and secondary schools integrated into public or private school system with 33,513 children and adolescents enrolled in the elementary school system.

\section{Sample characteristics}

A cross-sectional study was carried between February and June of 2007 of the prevalence of TDI among 12-year-old children at public and private schools in urban areas of the city of Montes Claros, Brazil.

The sample size was calculated to give a standard error of $2.0 \%$. A $95.0 \%$ confidence interval (CI) and $16.1 \%$ prevalence of traumatic dental injury (TFI) ${ }^{2}$ were used for the calculation. The minimum sample size needed to satisfy the requirements was estimated to be 343 individuals. A correction factor equal to 1.7 was applied for design effect (deff) ${ }^{36}$. To compensate for possible no-responses and/or refusals during the data acquisition phase, the sample was increased by $10 \%$, resulting in a total of 641 students.

For the selection of the sample, a list of schools located in urban areas, along with their addresses and the number of 12-year-old students enrolled, was acquired from the Board of Education of the state of Minas Gerais (southeastern Brazil). The schools were grouped based on their geographic location, in five districts. The sample was proportionally distributed. Approximately $1 / 3$ of the schools in each district of the city (approximately 7 school by district) were randomly selected by lots, ensuring an equal likelihood of participation for all public and private schools. The schoolchildren were selected using a systematic method. Subsequently, 17 schoolchildren from 38 schools ( 33 public and 5 private) were invited to participate in the study, totaling 641 students.

\section{Collection of non-clinical data}

A meeting was scheduled with parents/ guardians to explain the objectives, procedures and importance of the study. Those who agreed to the participation of their children signed a statement of informed consent and filled out a questionnaire addressing socioeconomic aspects. Children without authorization, those who wore an orthodontic appliance and those absent from school on the day of the clinical exam were excluded from the study. 
The following socioeconomic indicators were employed: type of school (public or private), monthly household income, mother's schooling and the criteria of the Brazilian Association of Advertisers (ABA-ABIPEME), was investigated using the questionnaire designed by the Brazilian Advertising Association/Brazilian Market Institute Association, which categorizes the Brazilian population into five classes [Classes A (high class), B, C, D and E (low class) $]^{2,13,19,37}$. Mother's schooling ${ }^{7,10,22,38,39}$ and marital status 10 were informed by the parents/guardians. Mother's schooling was dichotomized based on median values as 0 and 1 for $\leq 5$ years and $>5$ years study, respectively. Child's gender and date of birth were recorded during the clinical exam. The interviews and clinical exams were held at the respective schools in a private room at a previously scheduled date and time in order not to interfere with normal school activities.

\section{Clinical data collection}

The team was made up of a previously trained and calibrated examiner (P.C.P.P.), an annotator and an assistant who conducted the children to the examining room. The calibration exercise consisted of the use of color slides for each type of injury in the permanent dentition (two images of each injury). The results of the examinations were compared with the judgment of a dentist with experience in traumatology (gold standard). The calibration exercise was then performed for the clinical examination by both the examiner (P.C.P.P.) and the gold standard (M.I.C.), with the patients involved in this exercise examined a second time after a 15-day interval. These patients did not participate in the main study. The accuracy of the exam was measured with a second examination of $10 \%$ of the sample and the calculation of the Kappa statistic. Intra-examiner and inter-examiner agreement were determined using the Kappa index, the values of which were 0.96 and 0.87 , respectively. Values greater than 0.70 were considered satisfactory.

A pilot study was first conducted to test and adjust the methods. This pilot study involved a convenience sample of 30 students who were not included in the main study (15 public school and 15 private school).

The examiner recorded the type of damage sustained, any treatment or treatment needed because of TDI. The criteria adopted for TDI were those used in the Children's Dental Health Survey in the $\mathrm{UK}^{40}$. Such criteria included fractures, discoloration and tooth loss because of trauma in the permanent dentition. However, enamel cracks were also recorded. A standard school chair was used during the exam. Artificial lighting was used for a more precise detection of the criteria used for the identification of TDI. Care was taken to avoid cross contamination and the examiner used individual protection equipment during each exam. Sterilized mouth mirrors, dental probes and gauze were packed in sufficient numbers for each work day.

All permanent incisors were examined. For such, the teeth were cleaned and dried with sterilized gauze. A mouth mirror was used for the examination of all faces of the teeth and a probe was used to remove any residue. The presence and extent of esthetic restorations were also recorded.

Lip protection was evaluated using the method proposed by O'Mullane ${ }^{12}$. Lip protection was considered adequate when the lips covered the upper incisors in the resting position. Otherwise, lip protection was considered inadequate. Overjet was measured with the aid of a wooden tongue depressor with a straight tip. The bite was placed in centric occlusion and overjet was measured from the vestibular face of the lower incisor to the incisal vestibular face of the most prominent upper incisor, with a mark made on the tongue depressor in graphite. The distance from the edge of the tongue depressor to the mark was subsequently measured using a digital caliper. A distance greater than $5 \mathrm{~mm}$ was recorded as accentuated overjet.

\section{Ethical considerations}

This study received approval from the $\mathrm{Hu}$ man Research Ethics Committee of the Pontifícia Universidade Católica de Minas Gerais (Brazil). Health and education authorities were informed as to the objectives of the study, gave their authorization and offered the assistance of the respective government agencies for the conduction of the study. The parents/guardians signed a statement of informed consent. The participants were ensured anonymity and confidentiality regarding their responses.

\section{Statistical analysis}

Data analysis was performed using the Statistical Package for the Social Sciences (SPSS for Windows, version 17.0, SPSS Inc, Chicago, IL, USA) and included frequency distribution and 
association tests. Statistically significant associations between the independent variables and TDI were determined using the chi-square test. The dependent variable (TDI) and the independent variables having achieved a p-value $<0.20$ in the bivariate analysis were incorporated one-by-one into the Poisson logistic regression model in decreasing order of significance (stepwise backward procedure).

\section{Results}

The response rate was high, and only $0.47 \%$ ( $\mathrm{n}=$ 3 ) of the 641 students selected refused to participate in the clinical examination, with the final sample being composed by 605 students 12 -yearolds, representing a population of 6028 schoolchildren in this age group in the city of Montes Claros, Brazil. The systematic selection method was employed, with 38 proportionally distributed schools randomly selected and asked to participate. The response rate was high (94.3\%). Thirty-three children were excluded from the study for the following reasons: $22(3.3 \%)$ did not have authorization from their parents/guardians; one $(0.2 \%)$ was absent from school on the day of the exam; one $(0.2 \%)$ refused to participate; and nine $(1.5 \%)$ wore an orthodontic appliance. Thus, the final sample was made up of 605 12-year-olds and their parents/guardians.

The sample of 605 12-year-olds was made of 310 boys (51.2\%) and 295 girls (48.8\%). These findings are explained by the proportional selection of each type of school in the city. Most of the participants $(429 ; 70.9 \%)$ were enrolled in state-run schools; their parents were married (419; 69.7\%); mothers has less than five years of schooling (457; 75.5\%); and families belonged to socioeconomic classes with a low class (509; $84.1 \%)$. No significant associations were found between TDI and socioeconomic status (Table 1).

The prevalence of TDI in the permanent incisors of the 12 -year-olds analyzed was $3 \leq 4.9 \%$, with a slightly higher rate among boys (36.8\%) than girls (32.9\%). However, this gender difference did not achieve statistical significance $(\mathrm{p} \leq 0.315)$. Mean age at the time of occurrence was 9.6 years (standard deviation: 1.7 years). Among the 211 schoolchildren with a diagnosis of TDI, 149 were able to state their precise age at the time of occurrence.

Among the students with TDI, 55.5\% ( $\mathrm{n}=$ 116) had enamel fractures, $42.6 \%(n=89)$ had enamel and dentin fractures without pulp in- volvement, $1.9 \%(\mathrm{n}=4)$ had enamel and dentin fractures with pulp involvement, $2.9 \%(\mathrm{n}=$ 6) had discoloration. No cases of avulsion were found. Restoration with resin composite was found in $15.8 \%(n=33)$ and $2.9 \%(n=6)$ had bonded fragment.

The largest portion of the schoolchildren with traumatic dental injuries reported the home as the place of occurrence (71 participants; $48.2 \%$ ), followed by school (37 participants; 25.2\%). Falls constituted the main etiological factor (73 participants; $49.7 \%$ ), followed by collisions with objects or people (27 participants; $18.4 \%$ ) (Table 2).

Upper central incisors were the most affected. Traumatic dental injury was diagnosed in 103 (48.8\%) upper right central incisors and 106 (50.2\%) upper left central incisors, with no statistically significant difference between sides $(\mathrm{p}=$ 0.92). Dental trauma affected only one tooth in $161(76.3 \%)$ of the participants, two teeth in 41 $(19.5 \%)$ of the participants, three teeth in four

Table 1. Distribution of sample according to prevalence of traumatic dental injuries among 605 schoolchildren and independent variables (Montes Claros, Brazil).

\begin{tabular}{|c|c|c|c|}
\hline \multirow[b]{2}{*}{$\begin{array}{c}\text { Independent } \\
\text { variables }\end{array}$} & \multicolumn{2}{|c|}{ Traumatic dental injury } & \multirow[b]{2}{*}{$\begin{array}{c}\text { p- } \\
\text { value }^{*}\end{array}$} \\
\hline & $\begin{array}{l}\text { Present } \\
(\mathbf{n})(\%)\end{array}$ & $\begin{array}{l}\text { Absent } \\
\text { (n) (\%) }\end{array}$ & \\
\hline \multicolumn{3}{|l|}{ Gender } & \multirow{3}{*}{0.315} \\
\hline Male & $114(18.8)$ & $196(32.4)$ & \\
\hline Female & $97(16)$ & $198(32.7)$ & \\
\hline \multicolumn{3}{|c|}{ Socioeconomic class } & \multirow{3}{*}{0.069} \\
\hline Low $(\mathrm{CDE})$ & $179(29.6)$ & $344(56,9)$ & \\
\hline $\operatorname{High}(\mathrm{AB})$ & $32(5.3)$ & $50(8.3)$ & \\
\hline \multicolumn{3}{|l|}{ Mother's schooling } & \multirow{3}{*}{0.384} \\
\hline$\leq 5$ years & $155(25.6)$ & $302(49.9)$ & \\
\hline$>5$ years & $56(9.3)$ & $92(15.2)$ & \\
\hline \multicolumn{3}{|l|}{ Marital status } & \multirow{3}{*}{0.929} \\
\hline Married & $146(24.3)$ & $274(45.6)$ & \\
\hline $\begin{array}{l}\text { Divorced/ Single/ } \\
\text { Widowed }\end{array}$ & $63(10.6)$ & $118(19.6)$ & \\
\hline \multicolumn{3}{|l|}{ Type of school } & \multirow{4}{*}{0.652} \\
\hline State public & $145(24.0)$ & $284(46.9)$ & \\
\hline Municipal public & $38(6.3)$ & $66(10.9)$ & \\
\hline Private & $28(4.6)$ & $44(7.3)$ & \\
\hline \multicolumn{3}{|l|}{ Lip protection } & \multirow{3}{*}{0.231} \\
\hline Adequate & $119(19.7)$ & $247(40.8)$ & \\
\hline Inadequate & $92(15.2)$ & $146(24.1)$ & \\
\hline \multicolumn{3}{|l|}{ Overjet } & \multirow{3}{*}{0.001} \\
\hline$\leq 5 \mathrm{~mm}$ & $164(32.2)$ & $346(67.8)$ & \\
\hline$>5 \mathrm{~mm}$ & $47(40.5)$ & $48(50.5)$ & \\
\hline
\end{tabular}

" chi-squared test 
(1.9\%) of the participants, four teeth in three $(1.4 \%)$ of the participants and five teeth in two $(0.9 \%)$ of the participants.

Mean overjet was $3.2-1.6 \mathrm{~mm}$. The majority of participants $(310 ; 51.2 \%)$ had overjet less than $5.0 \mathrm{~mm}$ and $295(48.8 \%)$ had overjet greater than $5.0 \mathrm{~mm}$. Overjet could not be measured in 25 participants due to the presence of crossbite, open bite or overbite.

The chi-square test revealed a statistically significant association between accentuated overjet $(>5.0 \mathrm{~mm})$ and TDI $(\mathrm{p}=0.001)$. Adequate lip protection was observed in $119(32.5 \%)$ of the participants with TDI and 247 (67.5\%) without TDI. The chi-square test demonstrated no statistically significant association between lip protection and dental trauma $(\mathrm{p}=0.231)$.

The univariate logistic regression analysis revealed a statistically significant association between overjet and TDI, as the percentage of participants with overjet greater than $5 \mathrm{~mm}(49.5 \%)$ was higher than the percentage of participants with overjet equal to or less than $5 \mathrm{~mm}(32.2 \%)$ $(\mathrm{p}=0.001)$. Variables with a $\mathrm{p}$-value $<0.25$ in the univariate analysis were incorporated into the Poisson logistic regression model: overjet, socioeconomic level and lip protection (adjusted for gender). The prevalence of TDI was significantly higher among the participants with accentuated overjet $[\mathrm{PR}=1.50$ (95\% CI:1.41 to 1.61$)$; $p=0.003]$ independently of the other variables (Table 3).

\section{Discussion}

The prevalence of traumatic dental injuries to the permanent incisors among the 12-year-old schoolchildren analyzed in the present study was $34.9 \%$. This rate is higher than that reported in the majority of Brazilian studies employing a similar methodology $y^{2,5,8,22}$, but lower than the prevalence rate reported for the city of Blumenau, Brazil (58.6\%).

Although this study was conducted with 12 -year-olds, which is the age recommended by Andreasen et al. ${ }^{34}$ for epidemiological studies due to the fact that it is the end of the mixed dentition

Table 2. Distribution of factors related to dental injuries in 147 schoolchildren who experienced injuries to permanent incisors in Montes Claros, Brazil.

\begin{tabular}{lrrrrr}
\hline \multicolumn{1}{c}{ Etiology } & $\begin{array}{c}\text { House } \\
\mathbf{n}(\%)\end{array}$ & $\begin{array}{c}\text { School } \\
\mathbf{n}(\%)\end{array}$ & $\begin{array}{r}\text { Public recreation areas } \\
\mathbf{n}(\%)\end{array}$ & $\begin{array}{r}\text { Street } \\
\mathbf{n}(\%)\end{array}$ & $\begin{array}{r}\text { Total } \\
\mathbf{n}(\%)\end{array}$ \\
\hline Fall & $39(26.54)$ & $21(14.28)$ & $5(3.40)$ & $8(5.44)$ & $73(49.66)$ \\
Collision & $16(10.89)$ & $9(6.12)$ & $1(0.68)$ & $1(0.68)$ & $27(18.37)$ \\
Violence & $9(6.12)$ & $2(1.36)$ & $0(0)$ & $9(6.12)$ & $20(13.60)$ \\
Inanimate objects & $7(4.76)$ & $0(0)$ & $0(0)$ & $0(0)$ & $7(4.76)$ \\
Cycling & $0(0)$ & $0(0)$ & $0(0)$ & $12(8.17)$ & $12(8.17)$ \\
Sports accident & $0(0)$ & $5(3.40)$ & $1(0.68)$ & $32(21.36)$ & $8(5.44)$ \\
Total & $71(48.31)$ & $37(25.16)$ & $7(4.76)$ & $147(100)$ \\
\hline
\end{tabular}

Table 3. Risk factors for traumatic dental injuries among among 605 schoolchildren 12 -year-old schoolchildren (results of Poisson logistic regression analysis*) (Montes Claros, Brazil).

\begin{tabular}{lccccc}
\hline $\begin{array}{c}\text { Dependent } \\
\text { variable }\end{array}$ & $\begin{array}{c}\text { Independent } \\
\text { variables }\end{array}$ & $\begin{array}{c}\text { PR }(\mathbf{9 5 \%} \mathrm{CI}) \\
\text { Crude }\end{array}$ & $\boldsymbol{p}^{*}$ & $\begin{array}{c}\text { PR }(\mathbf{9 5 \%} \mathrm{CI}) \\
\text { Adjusted }\end{array}$ & $\boldsymbol{p}^{*}$ \\
\hline TDI & & & & 0.003 \\
& $\begin{array}{c}\text { Overjet } \\
\leq 5 \mathrm{~mm}\end{array}$ & 1.00 & 0.001 & 1.00 & 0.33 \\
& $>5 \mathrm{~mm}$ & $1.68(1.03-1.83)$ & & $1.50(1.41-1.61)$ & 1.00 \\
& $\begin{array}{c}\text { Lip protection } \\
\text { Adequate } \\
\text { Inadequate }\end{array}$ & $1.04(0.99-1.09)$ & & $1.02(0.98-1.08)$ \\
\hline
\end{tabular}

$\mathrm{TDI}=$ traumatic dental injury; $\mathrm{PR}=$ prevalence ratio; $\mathrm{CI}=$ confidence interval. ${ }^{\star}$ Adjusted for gender. 
and the period of a greater incidence of TDI, the findings indicate the existence of other variables not considered in studies of this nature. A clinical exam in a well-lit setting preceded by adequate cleaning of the crown surfaces and proper ergonomic positioning of the children may have allowed greater accuracy in the exams.

The high response rate in the present study was likely due to the sensitization model employed. The examiner had direct contact with both the administration of the school and the parents of the students, during which all questions were clarified and authorization was obtained, resulting in greater adherence. Twelveyear-olds with orthodontic appliances were excluded to ensure greater accuracy in the exams. Due to the epidemiological nature of the study, some conditions requiring complementary exams, such as the pulp vitality test or radiographs, may not have been identified.

Data analysis in cross-sectional epidemiological studies with binary outcomes often involves logistic regression, the association measure of which is the odds ratio (OR). However, some researchers state that the prevalence ratio (PR) is a natural measure for cross-sectional studies, especially when the prevalence rate is high, which could lead to an overestimated OR and broad confidence intervals. Therefore, Poisson logistic regression was used to determine the statistical significance of the associations between TDI and the independent variables in the present study ${ }^{41,42}$.

No statistically significant difference was found between genders with regard to TDI. However, the lack of gender difference diverges from the findings described in a large number of other studies, which report a greater occurrence of TDI among boys ${ }^{2,5,6,9,10,19-21}$. This finding may be the result of cultural changes in recent years, with girls exercising similar activities as boys.

Socioeconomic status exerts an influence on the causality of diseases in different ways depending on cultural aspects and is related to access to health services, health promotion actions, safe environments and protection equipment, which can affect the significance of variables on the individual level ${ }^{41}$. Thus, it is imperative to clarify this issue. Some authors argue that the divergent results found in literature are due to the different indicators adopted. A number of socioeconomic indicators have been employed in epidemiological studies, such as type of school (public or private), level of schooling of the head of the household or mother, household income, classification of socioeconomic status and the social vulnerability index ${ }^{35}$. There is no consensus in the literature on the best socioeconomic indicator or the association with TDI.

Different studies report an association with higher social classes ${ }^{2}$; others report an association with lower social classes ${ }^{10}$ and still others have found no such association ${ }^{22}$. Thus, several socioeconomic indicators were used in the present study and no statistically significant association was found between TDI and any of these indicators. The lack of a well-contextualized up-to-date indicator that addresses the different dimensions of socioeconomic status in an efficacious, objective manner may account for the divergences found in studies of this nature.

The largest portion of participants with dental trauma reported that the incident occurred at ten years of age. This finding is in agreement with those described in the majority of epidemiological studies, which report a peak age for traumatic dental injury between nine and 12 years ${ }^{12,24,34}$. A peak age of nine years is reported in studies carried out in Italy ${ }^{15}$ and Spain ${ }^{21}$ and a peak age of 10 years is reported in a study carried out in Iran?

The comparison of results regarding the type of injury is hindered by the lack of standardization in the classifications employed in different epidemiological studies. The classification used in the present investigation was similar to that employed in a study carried out in the United Kingdom ${ }^{40}$ and a number of other studies assessing the prevalence of TDI ${ }^{1,2,5-7,9-11,16,20,22}$. As reported in investigations using the same diagnostic criteria, enamel fracture was the most frequent injury, followed by enamel and dentin fracture without pulp exposure $e^{1,2,5-7,9-11,16,20,22}$. Esthetic restoration with a resin composite was the most frequent form of treatment, which is similar to findings reported in other Brazilian epidemiological surveys ${ }^{2,20,22}$. Few participants exhibited sequelae, such as edema, fistula and discoloration of the dental crown. These criteria are not included in other classifications.

Falls constituted the main etiological factor (49.7\%), followed by collisions with objects or people (18.4\%). Similar findings are reported in the literature $e^{7,810,13,23}$. Acts of violence are reported to be the main etiological factor for TDI among Syrian schoolchildren ${ }^{1}$. The etiology of dental trauma is correlated with cultural factors and the types of activities each community practices. None of the participants in the present study reported TDI stemming from a traffic accident. This may be explained by compliance 
with Brazilian traffic laws, which make the use of a safety belt and a special seat for children under seven years of age mandatory and children under 10 years of age must ride in the back seat ${ }^{41}$.

The largest portion of the schoolchildren with TDI reported the home as the place of occurrence $(48.2 \%)$. This is in agreement with findings reported in studies carried out in India ${ }^{13}$, Brazil $^{6}$, Nigeria ${ }^{23}$ and Iran $^{7}$.

The upper central incisors were the most affected by TDI, which is similar to findings reported in epidemiological studies throughout the world $\mathrm{d}^{2,7,8,12-15,20-22,24}$. In most cases, only one tooth was affected, which is also similar to findings reported in previous studies $2,13,15,24$.

No statistically significant association was found between TDI and lip protection. This result corroborates findings reported in other studies carried out in Brazil ${ }^{5,6,9,20}$. However, a number of studies employing a similar methodology report that children with inadequate lip protection are more prone to $\mathrm{TDI}^{2,8,12,16,17,22}$.

In the present study, overjet greater than 5 $\mathrm{mm}$ was classified as accentuated, as reported in previous studies ${ }^{16,25}$, and a significant association was found between accentuated overjet and the occurrence of TDI. Thus, the findings are in agreement with the literature regarding the need for interventional measures for the correction of this type of malocclusion, which predisposes individuals to TDI.

The World Health Organization encourages epidemiological surveys to evaluate trends within a given population as well as between populations of different countries, allowing the planning of health services and prevention programs as well as serving as the basis for future studies. Despite the growing number of papers on TDI published in Brazil, most involve populations located in the southern and southeastern regions of the country. As Brazil is rich in cultural, social and economic diversity, the present investi- gation was developed in northern portion of the state of Minas Gerais, which has close ties with the southern portion of the state of Bahia and regional characteristics that differ from those of the rest of the state.

The Brazilian public healthcare system has reorganized its priorities with regard to oral health care, adopting the health promotion model with interventions based on risk factors. Therefore, actions and services following this guideline need to adjust to the health situations of each location for the establishment of effective practices.

The present study has limitations that should be addressed. Despite the assurance of confidentiality, some findings may have been underestimated due to embarrassment or fear of answering affirmatively to questions on the etiology of TDI. Moreover, the cross-sectional design does not allow the determination of causality. Longitudinal and intervention studies are needed to address causes and consequences of TDI, it is fundamental to gain a better understanding of the etiology of TDI so that effective prevention strategies can be outlined.

\section{Conclusion}

There was an elevated prevalence of TDI among 12-year-old schoolchildren in the city of Montes Claros, Brazil. In the present study, gender, socioeconomic status and lip protection were not determinants of the outcome, whereas accentuated overjet was significantly associated with the occurrence of TDI. No association was found between TDI and the socioeconomic variable analyzed. However, further studies should be carried out to assess the association between traumatic dental injuries and socioeconomic indicators with the use of an assessment tool that addressing the social and economic dimensions of individuals in a more efficacious fashion.

\section{Collaborations}

PCP Paiva, HN Paiva, PM Oliveira Filho e MIS Côrtes participated equally in all stages of preparation of the article. 


\section{References}

1. Marcenes W, al Beiruti N, Tayfour D, Issa S. Epidemiology of traumatic injuries to the permanent incisors of 9-12-year-old schoolchildren in Damascus, Syria. Endod Dent Traumatol 1999; 15(3):117-123.

2. Cortes MI, Marcenes W, Sheiham A. Prevalence and correlates of traumatic injuries to the permanent teeth of schoolchildren aged 9-14 years in Belo Horizonte, Brazil. Dent Traumatol 2001; 17(1):22-26.

3. Otuyemi OD. Traumatic anterior dental injuries related to incisor overjet and lip competence in 12-year-old Nigerian children. Int J Paediatr Dent 1994; 4(2):81-85.

4. Ravishankar TL, Kumar MA, Ramesh N, Chaitra TR. Prevalence of traumatic dental injuries to permanent incisors among 12 year old school children in Davangere, South India. Chin J Dent Res 2010; 13(1):57-60.

5. Marcenes W, Alessi ON, Traebert J. Causes and prevalence of traumatic injuries to the permanent incisors of school children aged 12 years in Jaragua do Sul, Brazil. Int Dent J 2000; 50(2):87-92.

6. Marcenes W, Zabot NE, Traebert J. Socio-economic correlates of traumatic injuries to the permanent incisors in schoolchildren aged 12 years in Blumenau, Brazil. Dent Traumatol 2001; 17(5):222-226.

7. Navabazam A, Farahani SS. Prevalence of traumatic injuries to maxillary permanent teeth in 9- to 14-yearold school children in Yazd, Iran. Dent Traumatol 2010; 26(2):154-157.

8. Soriano EP, Caldas Júnior AF, Goes PS. Risk factors related to traumatic dental injuries in Brazilian schoolchildren. Dent Traumatol 2004; 20(5):246-250.

9. Taiwo OO, Jalo HP. Dental injuries in 12-year old Nigerian students. Dent Traumatol 2011; 27(3):230-234.

10. Damé-Teixeira N, Alves LS, Susin C, Maltz M. Traumatic dental injury among 12-year-old South Brazilian scholchildren: prevalence, severity, and risk indicators. Dent Traumatol 2013; 29(1):52-58.

11. Ramos-Jorge ML, Tataounoff J, Corrêa-Faria P, Alcântara CE, Ramos-Jorge J, Marques LS. Non-accidental collision followed by dental trauma: associated factors. Dental Traumatol 2011; 27(6):442-445.

12. O'Mullane DM. Injured permanent incisor teeth: an epidemiological study. J Ir Dent Assoc 1972; 18(4):160173.

13. David J, Astrøm AN, Wang NJ. Factors associated with traumatic dental injuries among 12-year-old schoolchildren in South India. Dent Traumatol 2009; 25(5):500-505.

14. Garcia-Godoy F, Morban-Laucer F, Corominas LR, Franjul RA, Noyola M. Traumatic dental injuries in schoolchildren from Santo Domingo. Community Dent Oral Epidemiol 1985; 13(3):177-179.

15. Petti S, Tarsitani G. Traumatic injuries to anterior teeth in Italian schoolchildren: prevalence and risk factors. Endod Dent Traumatol 1996; 12(6):294-297.

16. Glendor U. Epidemiology of traumatic dental injuries a 12 year review of the literature. Dent Traumatol 2008; 24(6):603-611.
17. Hamdan MA, Rajab LD. Traumatic injuries to permanent anterior teeth among 12-year-old schoolchildren in Jordan. Community Dent Health 2003; 20(2):89-93.

18. Locker D. Prevalence of traumatic dental injury in grade 8 children in six Ontario communities. Can J Public Health 2005; 96(1):73-76.

19. Soriano EP, Caldas Júnior AF, Diniz de Carvalho MV, Amorim Filho HA. Prevalence and risk factors related to traumatic dental injuries in Brazilian schoolchildren. Dent Traumatol 2007; 23(4):232-240.

20. Traebert J, Bittencourt DD, Peres KG, Peres MA, de Lacerda JT, Marcenes W. Aetiology and rates of treatment of traumatic dental injuries among 12-year-old school children in a town in southern Brazil. Dent Traumatol 2006; 22(4):173-178.

21. Livny A, Sgan-Cohen HD, Junadi S, Marcenes W. Traumatic dental injuries and related factors among sixth grade schoolchildren in four Palestinian towns. Dent Traumatol 2010; 26(5):422-426.

22. Traebert J, Marcon KB, Lacerda JT. Prevalence of traumatic dental injuries and associated factors in schoolchildren of Palhoça, Santa Catarina State. Cien Saude Colet 2010; 15(Supl. 1):1849-1855.

23. Adekoya-Sofowora CA, Adesina OA, Nasir WO, Oginni AO, Ugboko VI. Prevalence and causes of fractured permanent incisors in 12-year-old suburban Nigerian schoolchildren. Dent Traumatol 2009; 25(3):314-317.

24. Jamani KD, Fayyad MA. Prevalence of traumatized permanent incisors in Jordanian children, according to age, sex and socio-economic class. Odontostomatol Trop 1991; 14(2):17-20.

25. Glendor U. Aetiology and risk factors related to traumatic dental injuries-a review of the literature. Dent Traumatol 2009; 25(1):19-31.

26. Côrtes MIS, Bastos JV. Epidemiologia do traumatismo dentário. Pro-odonto Prevenção 2011; 5:113-149.

27. Malikaew P, Watt RG, Sheiham A. Prevalence and factors associated with traumatic dental injuries (TDI) to anterior teeth of 11-13 year old Thai children. Community Dent Health 2006; 23(4):222-227.

28. Bourguignon C, Sigurdsson A. Preventive strategies for traumatic dental injuries. Dent Clin North Am 2009; 53(4):729-749.

29. Borum MK, Andreasen JO. Therapeutic and economic implications of traumatic dental injuries in Denmark: an estimate based on 7549 patients treated at a major trauma centre. Int J Paediatr Dent 2001; 11(4):249-258.

30. Wong F, Kolokotsa K. The cost of treating children and adolescents with injuries to their permanent incisors at a dental hospital in the United Kingdom. Dent Traumatol 2004; 20(6):327-333.

31. Antunes LAA, Leão AT, Maia LC. Impacto do traumatismo dentário na qualidade de vida de crianças e adolescentes: revisão crítica e instrumentos de medida. Cien Saude Colet 2012; 17(12):3417-3424. 
32. Cortes MI, Marcenes W, Sheiham A. Impact of traumatic injuries to the permanent teeth on the oral health-related quality of life in 12-14-year-old children. Community Dent Oral Epidemiol 2002; 30(3):193-198.

33. Ramos-Jorge M, Bosco V, Peres M, Nunes A. The impact of treatment of dental trauma on the quality of life of adolescents: a case-control study in southern Brazil. Dent Traumatol 2007; 23(2):114-119.

34. Andreasen JO, Andreasen FM. Anderson L. Textbook and color atlas of traumatic injuries to the teeth. $4^{\text {rd }} \mathrm{ed}$. Copenhagen: Munskgaard International Publishers; 2007. p. 897.

35. Bendo CB, Scarpelli AC, Vale MP, Araújo P, Zarzar PM. Correlation between socioeconomic indicators and traumatic dental injuries: a qualitative critical literature review. Dent Traumatol 2009; 25(4):420-425.

36. Pearce N. Effect measures in prevalence studies. Environ Health Perspect 2004; 112(10):1047-1050.

37. ABA-ABIPEME. Critério padrão de classificação econômica Brasil. 2008. [acessado 2007 jan 15]. Disponível em: http://www.viverbem.fmb.unesp.br/docs/ classificacaobrasil.pdf

38. Meneghim MC, Kozlowski FC, Pereira AC, Ambrosano GMB, Meneghim ZMP. Classificação socioeconômica e sua discussão em relação à prevalência de cárie e fluorose dentária. Cien Saude Colet 2007; 12(2):523-529.

39. Martins RJ, Garcia AR, Garbin CAS, Sundefeld MLMM. Relação entre classe socioeconômica e fatores demográficos na ocorrência da disfunção temporomandibular. Cien Saude Colet 2008; 13(Supl. 2):20892096.

40. O'Brien M. Children's dental health in the United Kingdom 1993. In: Report of Dental Survey, Office of population Censuses and Survey. London: Her Majesty's Stationery Office; 1995.

41. Feldens CA, Kramer PF, Fakhruddin KS, Al Kawas S. Socioeconomic status and traumatic dental injuries. Dent Traumatol 2013; 29(3):248-250.

42. Francisco SS, Filho FJ, Pinheiro ET, Murrer RD, Jesus Soares A. Prevalence of traumatic dental injuries and associated factors among Brazilian schoolchildren. Oral Health Prev Dent 2013; 11(1):31-38.

Apresentado em 19/03/2014

Aprovado em 10/09/2014

Versão final apresentada em 23/09/2014 
